\title{
Ki volt a magyar Lister? Gotthardt Károly (1835-1883) pozsonyi sebész fóorvos emlékezete
}

A Semmelweis-emlékév apropóján 2015-ben kiadott magyar-angol nyelvü emlékkönyvben Varga Benedek hívja fel a figyelmet a New York-i publicista, Robert A. Wilson alkotta Semmelweis-reflex kifejezésre [1]. A Semmelweis-reflex lényege: a nyilvánvaló automatikus elutasítása. Ez a tudománnyal egyidős, ösztönös emberi reakció volt az egyik oka, hogy kortársai, kollégái olyan sokáig elutasították Semmelweis felfedezését. Semmelweis kudarca, felismerésének mostoha sorsa jól ismert. Kevésbé köztudott, hogy a gyakran a „sikertelen” Semmelweisszel szembeállított „sikeres” - felfedezésével a lordi címet kiérdemlő - Joseph Lister (1827-1912) is részesült felfedezése elutasításában. Lister 1867. március 16-án kezdte meg öt részből álló tanulmánya publikálását a Lancet hasábjain: „The antiseptic system: on a new method of treating compound fracture, abscess, etc.; with observations on the conditions of suppuration". A hosszú cím indokolt volt - Lister ezzel kívánta felhívni a figyelmet a dolgozatban szereplő gondolatok alapvető fontosságára [2]. Nos, a figyelemfelhívás sikerült, ám felfedezése alapvető fontosságát éppen a szigetországbeli kollégái kérdőjelezték meg. Az ő esetében is beigazolódott az a régi bölcs mondás: senki sem próféta a saját hazájában [3], illetve múködésbe lépett modern változata: a Semmelweis-reflex. A hưvös angliai, illetve amerikai fogadtatás történetét többen feldolgozták [2-4]. Hasonlóan ismert az európai, elsősorban német pozitív fogadtatás.

De milyen volt a magyar fogadtatás? Ki volt/lehetett a „magyar Lister”? A kérdésfelvetést nem a nemzeti hiúság, büszkeség indokolja, hanem egyszerúen az a tény, hogy a listeri gyakorlat elfogadása vagy elutasítása emberéletek megmentését vagy elvesztését jelenthette. Sajnos, a magyar szakirodalomban nem találtam pontos, hiteles választ a feltett kérdésre. Egy 1996-os Lister-tanulmányban csak ennyi olvasható: „Az új módszer, minden újszerúsége és körülményessége ellenére, ha nem is gyorsan, tért hódított elsősorban az akkori világviszonylatban is vezetô német sebészek (Nussbaum, Thiersch, Volkmann, Langenbeck stb.) és a fiatal nemzedék körében” [5]. A „felsőoktatási segédkönyvként” kiadott, azaz a magyar medikusok képzését szolgáló „Orvostörténelem" sem foglalkozik a magyar vonatkozásokkal: „Módszerét a kontinensen elsősorban a német sebészek
(A. W. Schultze a berlini Charitéből, W. Hagedorn Magdeburgból, R. von Volkmann Halléból és J. N. Nussbaum Münchenbőll) alkalmazzák" [6]. A Semmelweis és Lister tudományos teljesítményével foglalkozó alapos tanulmány sem ír a magyarországi visszhangról, csupán azt jegyzi meg: „Lumnitzer listerista lett, az aszepszist értsd: Semmelweis tanát (K. L.) - akkor elhanyagolható ócskaságnak tekintette" [7]. Lumniczer Sándor (18211892 ) „listerista” voltát erősíti meg a mindmáig legjobb életrajza Antall József tollából: „Lumniczer ... a másik sebészprofesszorral, Kovács Józseffel együtt a semmelweisi asepsis gondolatában élt, később a Lister-féle antiseptikus sebkezelési eljárás magyarországi bevezetője lett" [8].

Egy korábbi dolgozatomban jómagam is Lumniczert tekintettem nemcsak Magyarországon, hanem az Osztrák-Magyar Monarchiában is a listeri tanok bevezetőjének [9]. Ez a dolgozat akkor „tiltakozás” volt egy 1989ben Prágában kiadott cseh orvostörténeti jegyzet állítása ellen. A jegyzet szerint ugyanis a cseh gyökerü Eduard Albert (1841-1900) professzor Innsbruckban, 1875. október 10-én, a Monarchia területén elsőként alkalmazta az antiszeptikus kezelést. (Albert később, 1881-
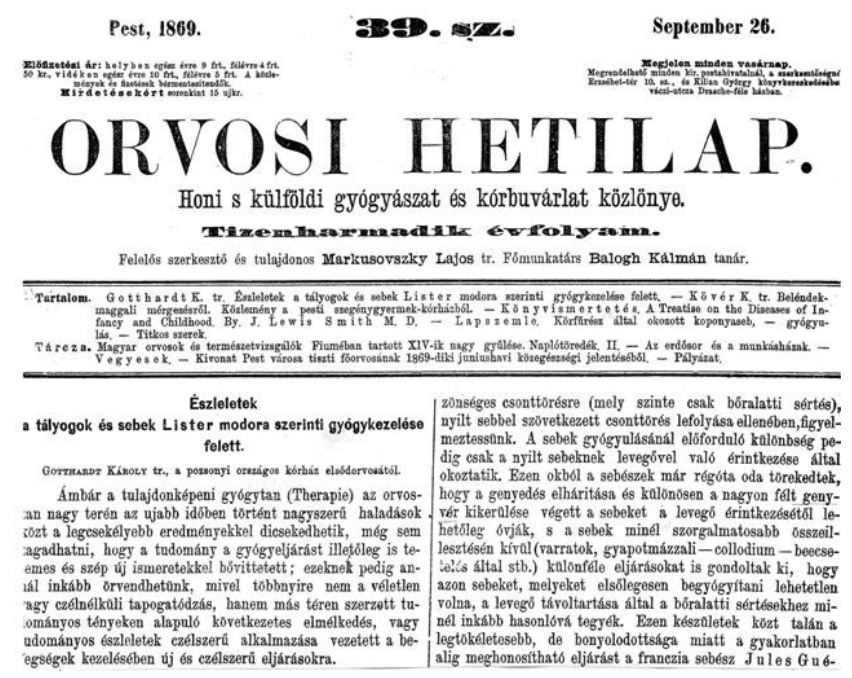

1. ábra | Gotthardt közleménye a Lister-féle „modorról” az Orvosi Hetilapban, 1869-ben 
től haláláig az I. sebészeti klinika igazgatója Bécsben.) Ismerve Lumniczer 1870-es közlését [10] - elsőbbsége vitathatatlannak tünt (legalábbis Alberttel szemben). Nos, az Albert prioritását erősítgető állítás - változatlan módon - újra felbukkant a róla írt legfrissebb monográfiában is [11]. Ez késztetett az újabb kutatásra, amelynek eredményeként azonban Lumniczer elsősége is „veszélybe került".

Lumniczer ugyanis az említett, 1870. december 11én, az Orvosi Hetilap 50. számában indított dolgozatában így ír: „Dittel tanár, Bécsben az elsők egyike volt, ki már 1868-ban a bécsi orvosegylet egyik gyúlésén jelentést tett kórosztályán e gyógymodorral foganatosított kísérletek kedvező eredményérôl. Az »OHL« 1869-ki folyamában is Gotthard (!), pozsonyi főorvos, az ez úton észlelt kedvező lefolyású esetek egész sorozatát közli." Vagyis Bécsben már 1868-ban, a hozzá közeli Pozsonyban pedig 1869-ben alkalmazták a Lister-féle „modort”.

Mielőtt ismertetnénk a Pozsonyban történteket, ejtsünk pár szót a mára méltatlanul elfeledett - s rövid ideig a felvidéki Trencsén-Teplicén is múködött - Leopold Dittelről (1815-1898). A morvaországi Fulnek városkából származó Dittel 1848-tól Johann Dumreicher (18151880 ) professzor első tanársegéde az I. sebészeti klinikán. Dumreicher az új bécsi iskola azon tagjai közé tartozott, akik ismételten kiálltak Semmelweis mellett [12]. Dittel 1861-tôl a bécsi „Általános Kórház” III. osztályának főorvosa és rendkívüli egyetemi tanár. Nemcsak kiváló (általános) sebész, hanem az urológia egyik úttörője is - Billroth kézikönyvébe ő írta meg a húgycső sebészetét. S ami témánk szempontjából a legfontosabb: „... A Lister-féle antiszeptikus kötést ő alkalmazta először Ausztriában Dumreicher ellenkezése dacára" [13].

Dittel tehát a legfóbb fórumot képező sebészeti klinikák igazgatói (Dumreicher az I., Billroth a II. sebklinikán) ellenére saját osztályán már 1868-ban bevezette a Lister-féle sebkezelést. Kedvező eredményeiről szóló beszámolóját a bécsi Orvosegyletben hallhatta a közeli Pozsonyban múködő Gotthardt Károly (1835-1883) is. Dittelt személyesen ismerhette, hiszen orvosi tanulmányait Bécsben végezte - 1858-ban szerzett orvosi, sebészi és szülészi oklevelet -, illetve 1864-ig a bécsi „közkórházban", Dittel osztályán volt másodorvos. Innen került az 1864. október 29-én megnyitott Pozsonyi Országos Kórház sebészetének élére. 1873-ig - Ambró János (1827-1890) kinevezéséig - ő látta el a szülészeti osztály felügyeletét is [14]. Ez utóbbi megbízatása szintén közrejátszhatott abban, hogy 1865-ben jelentkezett a pesti orvosi kar - Semmelweis halálával megürült - szülészeti tanszékére kiírt pályázatára. Sikertelenül: Diescher Jánost nevezték ki [15]. Gotthardt tehát maradt Pozsonyban. Társszerkesztője lett a magyarországi kórházügy első folyóiratának, az 1865 januárjában indult Kór házi Szemlének. Az Orvosi Hetilap (1857-től) és a Gyógyászat (1861-től) mellett megjelenő új szaklap szerkesztő-tulajdonosa, Gotthardt kollégája, a pozsonyi kórház bujakór- és bőrbetegosztályának fooorvosa, ifj. Zla- mál Vilmos (1831-1873) volt. Gotthardt lett az új lap egyik legszorgalmasabb szerzője. Sebészeti és nőgyógyászati témájú írásai közül kiemelkedik a „Paizsmirigydaganat mint megfulladásnak oka. Eredmény nélküli légcsőmetszés. - Bonclelet" című kazuisztikája. A benne leírt légcsőmetszés lehetett az első ilyen típusú beavatkozás a Felvidéken, a mai Szlovákia területén [16]. Sajnos, a lap 1866-ban - 2. évfolyamként már Orvosi Szemle címmel - megszünt.

Valószínú, hogy Gotthardt említett írásait anyanyelvén, német nyelven írta meg - fordítójuk személye ismeretlen. Hiányos magyar nyelvtudása miatt nem jöhetett szóba Semmelweis utódaként sem a fentebb említett pályázaton. Valószínú, hogy emiatt nem vett részt 1865 nyarán a magyar orvosok és természetvizsgálók XI. pozsonyi vándorgyúlésén sem. Bekapcsolódhatott viszont az 1856-tól múködő és a németet a magyarral egyenrangú tárgyalási nyelvként elfogadó pozsonyi Verein für Naturkunde (Természettudományi Egyesület) munkájába. Az egylet egyre erősödő orvosi szakosztálya havonta ülésezett - sajnos, az ülésekról nem maradtak fenn feljegyzések. Az egyesület titkára Gotthardt kollégája, az egykori országos szemész, az Országos Kórház szemészetének föorvosa, Kanka Károly 1871-ben Gotthardt segítségével adta ki az egyesület közleményeinek 10. kötetét. Ekkorra az orvosi szakosztály előadásainak száma felülmúlta a természettudományi osztályban elhangzottakét - ezért az egyesület már a Verein für Natur- und Heilkunde (Természet- és Orvostudományi Egyesület) név alatt szerepel. 1876-ig Gotthardt volt az orvosi szakosztály jegyzője [17].

Az eddig felsoroltakból nyilvánvaló, hogy Gotthardt jól képzett, az újabb orvosi ismeretek iránt nyitott és bécsi indíttatása révén valószínúleg - a bécsi orvosi körökkel aktív kapcsolatot tartó, nemcsak a szikét, hanem a tollat is jól kezelő sebészorvos volt. Nem meglepő tehát, hogy - jelenlegi ismereteink, kutatásaink alapján - őt tekinthetjük Lister első magyarországi követőjének. Az Orvosi Hetilap hasábjain 1869 öszén megjelent háromrészes dolgozata egyben a listeri tanok egyik első magyar ismertetése is [18]. Az írás fontos orvostörténeti adatokat tartalmaz: „Németországban legelőször a híres sebész, Thiersch tanár klinikáján Lipcsében alkalmaztatott az új modor, s Joseph tudor (Dissertatio inauguralis, Lipsie 1867) 16 esetet közölt, melyekben különösen tályogoknál... igen kedvező eredmény tapasztaltatott. A Lister-féle eljárás majd sok más kórodában is megpróbáltatott, s annak kedvező eredménye tapasztaltatott, úgy hogy mai napig gyakorlati értéke és hasznossága minden kétségen kívül van" (idézet a 647. oldalról). Az idézett szöveghez fontos lábjegyzet kapcsolódik, amely megerősíti feltételezésünket Gotthardt szoros bécsi kapcsolatairól: „Englisch tudor a bécsi orvos-egylet 1868iki novemb 27-én tartott gyưlésében a bécsi általános kórodából különösen Dittel tanár osztályán nagy kiterjedésben tett tapasztalatokat és kedvező eredményeket közölt." 
Értékes adalék a következő lábjegyzet is, amelyből kiderül, hogy Gotthardt tudott arról is, hogy Lister a karbolsav eredeti 1:4 hígítását később 1:6-ra változtatta és a hígításhoz lenmagolajat használt. „Kísérleteinknél mi is ezen aránynál maradtunk, csakhogy a drágább lenmagolaj helyett a nálunk olcsóbb faolajat vettük használatba.” Gotthardt közli az erre vonatkozó vényeket („rendelvényeket") is.

A dolgozat részletes elemzésétől eltekintek, meghagyva azt egy, a magyar sebészettörténetet monografikusan feldolgozó szerző számára.

Gotthardt közleményének első része 1869. szeptember 26-án jelent meg az Orvosi Hetilap címoldalán (1. ábra). Lumniczer főorvos a Rókus Kórházban 1869. november elsején indítja meg az 1870. október végéig tartó kísérleteinek sorozatát. Tapasztalatai közreadásakor Gotthardt egy évvel korábbi közlésében közzétett „kedvező lefolyású eseteinek egész sorozatára” is hivatkozik.

A teljesség kedvéért tegyük hozzá, hogy Gotthardt 1869-ben publikált még egy tanulmányt az Orvosi Hetilapban, pontosabban annak a „Közegészségügyi és törvényszéki Orvostan” címú mellékletében. Az „Észrevételek a Magyarország területén felállítandó bába-iskolákat illetőleg tett indítvány felett" címú írása is hozzájárult ahhoz, hogy 1873-ban Pozsonyban megnyílhatott a „bábaképezde”. Igazgató-tanára a már említett Ambró János lett. A bábaképezde azonban nem kapott önálló épületet, hanem az Országos Kórház „szülosztálya bábaképezdének engedtetett át” [19]. Első meglátásra ezzel Gotthardton is segítettek, hiszen levették vállairól a szülészeti osztály felügyeletének gondjait. Viszont az antiszepszis/aszepszis szempontjából érdekes helyzet alakult ki: a sebészeti osztály fóorvosa Lister, a szülészeti osztály (bábaképezde) vezetője Semmelweis elkötelezett híve volt. További kutatással talán kideríthető lesz: okozott-e ez konfliktust a két fóorvos kapcsolatában? Mennyire irányult Gotthardt (és osztálya) ellen Ambró szenvedélyes hangú, a Gyógyászat hasábjain megjelent levelének e kitétele: „Semmelweis tana jelenben - értsd: 1880-ban (K. L.) - az egész világon ünnepli megérdemlett diadalát, csak honfitársai ignorálják: szerencsétlen hazájában, egy országos bábaképezdén nincs helyiség a beteg gyermekágyasoknak az egészségesektől való elkülönítésére" [19].

Gotthardt írásban nem reagált. Nem tudni miért, de 1869 után többet nem publikált. A haláláig eltelt 14 évről nemigen található Gotthardtot érintő adat. Fiatalon, 48 éves korában, 1883. szeptember 26-án hunyt el. Utóda egy újabb „listeriánus”, a kiváló Lumniczer-tanítvány, Schmid Hugó lett [20].

A közelgő Lister-évforduló - 2017-ben lesz 150 éve annak, hogy megjelent első közleménye a karbolsavas antiszepszisről - jó alkalom lesz arra is, hogy igazoljuk: a magyar(országi) orvosok mindig gyorsan reagáltak az orvostudomány újabb felfedezéseire. Erre már csak azért is érdemes felhívni a listeri tan történetét kutatók figyelmét, mivel az egyik legmegbízhatóbb, német szerző tollából származó Lister-életrajz nem említi sem Gotthardt, sem Lumnitzer, de még a bécsi Dittel nevét sem [21].

\section{Irodalom}

[1] Varga, B.: How Semmelweis became a symbol. In: Monos, E. (ed.): In memory of Ignatius Semmelweis. [Semmelweis, mint jelkép. In: Monos, E. (szerk.): Semmelweis Ignác emlékezetére.] Semmelweis Kiadó, Budapest, 2015. [Hungarian]

[2] Nuland, S. B.: Doctors. The illustrated history of medical pioneers. Black Dog and Leventhal Publishers, Inc., New York, 2008.

[3] Thorwald, J.: Century of the surgery. [Das Jahrhundert der Chirurgie.] Steingrüben Verlag, Stuttgart, 1956. [German] (Hungarian translation: A sebészek évszázada. Gondolat Kiadó, Budapest, 1959. )

[4] Morris, R. T.: Fifty years being a surgeon. New York, 1935 (Czhech translation: Padesát let chirurgem. Nakladatelství Škubal, Praha, 1946.)

[5] Ihász, M.: Sir Joseph Lister (1827-1912). [Sir Joseph Lister (1827-1912).] Orv. Hetil., 1996, 137(52), 2927-2929. [Hungarian]

[6] Nemes, Cs.: History of medicine. (Orvostörténelem.) Debreceni Egyetem, Orvos- és Egészségtudományi Centrum, Debrecen, 2008. [Hungarian]

[7] Jendrassik, L.: The achievements of Semmelweis and Lister as seen by a research worker in biology today [Semmelweis és Lister teljesítményei egy mai élettan-kutató megvilágításában.] Communicationes ex Bibliotheca Historiae Medicae Hungarica, 1962, 25, 90-120. [Hungarian]

[8] Antall, J.: Sándor Lumniczer (1821-1892). In: Réti, E. (ed.): Masters of the Hungarian medical school. [Lumniczer Sándor (1821-1892). In: Réti, E. (szerk.): A magyar orvosi iskola mesterei.] Medicina Könyvkiadó, Budapest, 1969. [Hungarian]

[9] Kiss, L.: Eduard Albert - the Czech fighter for antisepsis. [Eduard Albert - az antiszepszis cseh apostola.] Orv. Hetil., 1991, 132(4), 203-204. [Hungarian]

[10] Lumniczer, S.: My one-year experience in therapy by Lister. [A Lister-féle gyógyeljárás körül gyűjtött egy évi tapasztalataim.] Orv. Hetil., 1870, 14(50), 837-840., (51), 854-861, (52), 869873. [Hungarian]

[11] Kokešová, H.: Eduard Albert (1841-1900). A Czech intellectual in Vienna. [Eduard Albert (1841-1900). eský intelektuál ve Vídni.] Vyšehrad, Praha, 2014,. [Czech]

[12] Benedek, I.: Semmelweis and his era. [Semmelweis és kora.] Gondolat Könyvkiadó, Budapest, 1967, [Hungarian]

[13] M(angold), L.: Lipot Dittel. In: Pallas Great Encyclopedia. Volume 17, (I. pótkötet).] Budapest, 1900. [Hungarian]

[14] Kiss, L.: A short history of the National Hospital in Bratislava (1864-1919). [A pozsonyi Országos Kórház „rövid” története (1864-1919]. Orv. Hetil., 2014, 155(44), 1768-1771. [Hungarian]

[15] Györy, T.: The history of the medical faculty 1770-1935. [Az orvostudományi kar története 1770-1935]. Budapest, 1936. [Hungarian]

[16] Kiss, L.: The "Hospital Review" in 1865 - the first journal for hospital service in Hungary. [Az 1865-ös pozsonyi Kórházi Szemle - a magyarországi kórházügy első folyóirata.]. Comm. de Hist. Artis Med., 2001, 174-177, 113-123. [Hungarian]

[17] Fischer, J.: The history of Medical and Natural-Science Society in Bratislava 1856-1906. [A pozsonyi Orvos-Természettudományi Egyesület története 1856-1906.] In: Fischer, J., Ortvay, T., Po- 
likeit, K. (eds): Memorial. [A Pozsonyi Orvos-Természettudományi Egyesület története 1856-1906. In: Fischer, J., Ortvay, T., Polikeit, K. (szerk.): Emlékmú.] Pozsonyi Orvos-Természettudományi Egyesület, Pozsony, 1907. [Hungarian]

[18] Gotthardt, K.: Observations of therapy of abscess and wound by Lister. [Észleletek a tályogok és sebek Lister modora szerinti gyógykezelése felett.] Orv. Hetil., 1869, 13(39), 645-648. (40), 677-680., (41), 693-697. [Hungarian]

[19] Ambro, J.: Deficiencies of national hospital and school of midwifery in Bratislava. [A pozsonyi országos közkórház és a bábaképezde hiányai.g Gyógyászat, 1880, 20. szám, Államorvos c. melléklet, 129-132, 140-143. [Hungarian]
[20] Kiss, L.: A forgotten student of Lumniczer: Hugo Schmid (1852-1912), head surgeon in Pressburg (Bratislava). [Egy elfeledett Lumniczer-tanítvány: Schmid Hugó (1852-1912), pozsonyi foorvos.] Orv. Hetil., 2002, 143(24), 1483-1486. [Hungarian]

[21] Genschorek, W.: Pioneers of surgery. Lister. Bergmann. (Wegbereiter der Chirurgie. Lister. Bergmann.) Leipzig, 1984. [German]

(Kiss László dr., SK-93 008 Csilizradvány 284., Szlovákia e-mail: kiss.agi@panelnet.sk)

HUMAN BioPlazma Kft. az egyetlen hazai vérkészítmény-gyártó vállalat, 2007 decembere óta a Kedrion csoport tagja. A Kedrion Biopharma szektorában az ötödik helyet foglalja el és több mint 40 országban van jelen a világon. A csoport többek között kísérleti és alkalmazott kutatásokat is végez, élen jár a technológiai transzferben és elkötelezett híve a nemzeti önellátás támogatásának és a ritka betegségek elleni küzdelemnek. Az emberi vérplazma ipari méretű feldolgozása hazánkban 1954-ben kezdődött, a gödöllői gyár közel 50 éve folyamatosan készít vérplazmából életmentő gyógyszereket, mint például albumint, immunglobulinokat és véralvadási faktorokat, elsősorban a hazai betegellátást szolgálva. A Kedrion Biopharma közreműködésével a hazai leányvállalat az elmúlt években termelő beruházások sorát valósította meg 50 millió eurót meghaladó értékben és ezzel a gödöllői gyár meghatározó szerepet tölt be a Kedrion Biopharma gyártóhelyei között.

KEDPLASMA $M A G Y A R O R S Z A ́ G$

\section{KÜLFÖLDI TULAJDONBAN LÉVŐ GYÓGYSZERGYÁRTÓ VÁLLALAT FELVÉTELT HIRDET}

\section{Plazmaferezis központ vezető pozícióba}

\section{Feladat}

- A központ tevékenységének teljes körű irányítása, koordinálása

- A termelési terv kidolgozása, teljesítése, ellenőrzése

- Eljárási utasítások írása, ellenőrzése, jóváhagyása

- A központ dolgozói, orvosai munkájának irányítása, felügyelete, oktatások szervezése

- Partnerekkel, beszállítókkal történő kapcsolattartás, részvétel beszállítói, partneri auditokon,

- Donorok, donorjelöltek vizsgálata, donornevelési program kialakítása, panaszok kezelése

- Eltérések azonosítása, deviációk indítása, a minőségbiztosítással együttműködve

- Vonatkozó előírások betartása betartatása (higiénés, minőségbiztosítási, munkabiztonsági, stb.)

\section{Elvárás}

- Orvosi diploma

- 5 éves szakmai tapasztalat Hematológus, belgyógyász, infektológus szakvizsga előnyt jelent

- Vezetői tapasztalat

- Középfokú angol nyelvtudás előnyt jelent

Pozitív tulajdonságok

- Önállóság, elkötelezettség

- Empátia, csapatszellem, rugalmasság, jó konfliktuskezelő képesség

- kiváló kommunikációs képesség

- jó szervező és problémamegoldó képesség, minőségtudatosság

Egyéb információk

- alkalmazotti jogviszonyban, teljes munkaidőben történő munkavégzés

\section{Donorvizsgáló orvos pozícióba}

\section{Feladat}

- Donorok azonosítása

- Donorok, donorjelöltek alkalmasságának elbírálása, orvosi vizsgálat, kórelőzmény, panaszok figyelembevételével

- Donorpanaszok fogadása, kivizsgálása, összefoglaló jelentés készítése

- Tájékoztatás a donáció folyamatáról

- Donorok kizárása, kizárás feloldása

- Donorkizárási kritériumok szigorú betartása

- Ügyel a donorok biztonságára, velük bizalomra épülő partnerkapcsolat alakít ki

- Higiénés előírások betartása, betartatása

Elvárás

- Orvosi diploma
- 3 éves szakmai tapasztalat

- Hematológus, belgyógyász, transzfúziológus, infektológus szakvizsga előnyt jelent

Pozitív tulajdonságok

- Önállóság, elkötelezettség

- Empátia, csapatszellem, rugalmasság, jó konfliktuskezelö képesség

- kiváló kommunikációs képesség

- jó szervező és problémamegoldó képesség, minőségtudatosság

Egyéb információk

- alkalmazotti jogviszonyban teljes/részmunkaidőben történő munkavégzés

- vállalkozási jogviszony

- megbízási jogviszony

Munkavégzés helye: Pécs vagy Debrecen. Jelentkezéseket a hr@humanked.com e-mail címre várjuk 